Reviews in Digital Humanities • Vol. 3, No. 1

\title{
Review: The Penn \& Slavery Project
}

Elizabeth Losh ${ }^{1}$

${ }^{1}$ William \& Mary

Published on: Jan 18, 2022

DOI: 10.21428/3e88f64f.7ffefa591

License: Creative Commons Attribution 4.0 International License (CC-BY 4.0). 


\section{Project}

The Penn \& Slavery Project

\section{Project Director}

Kathleen Brown, University of Pennsylvania

\section{Project URL}

http://pennandslavery.project.org/

\section{Project Reviewer}

Elizabeth Losh, William \& Mary

\section{Project Overview}

\section{Kathleen Brown}

Created by an interdisciplinary team of historians, librarians, developers, and designers, the Penn \& Slavery Project is based on student research into the University of Pennsylvania's historical complicity in slavery. Beginning in 2017, students combed the university archives and local repositories to uncover documents linking trustees and faculty to slavery and the slave trade. Their research exposed the early university's fundraising efforts among enslavers, the labor of an enslaved man on campus, and the use of enslaved and free Black people's bodies to further medical education and scientific research that supported slavery and other colonial projects.

The Penn \& Slavery Augmented Reality (AR) app that resulted is the first of its kind among institutions investigating their historic ties to slavery. The app takes users on a tour of slavery's legacy at Penn in six stops, each telling a story through an AR experience based on student research. Users begin with an introduction to Caesar, an enslaved man who labored without pay at Penn, and an account of early university fundraising efforts in Jamaica and South Carolina, two of the wealthiest slaveholding regions in the Atlantic World. The tour includes stops at the Penn Museum for an exhibit on the discredited science of craniology, a visit to a complex of dorms named after enslavers, and a memorial to the first Black medical practitioner educated at Penn Medical School despite being denied formal access to classes. The final stop features a 3D scan of Breanna Moore's family quilt. Moore, a recent Penn alum, shares the genealogical research that revealed her ancestors' enslavement by two Penn- 
educated doctors, a father and son. After initially designing for on-campus use, we decided to make the app available to all users no matter their location.

Student researcher VanJessica Gladney led the effort to create a website for the project to widen our audience beyond those who attended presentations. In exploring this option, Monument Lab scholars Laurie Allen and Paul Farber encouraged the use of AR to make this history visible on Penn's campus. With support from the Provost's and President's offices, Penn Libraries, and an internal grant, Allen assembled a team of student developers and designated undergraduate Dallas Taylor as the project manager. Digital humanities scholars Meaghan Moody and Katie Rawson joined the team in 2019, and we partnered with professionals at Dream Syndicate to finalize the app. We worked through the COVID closures and funding freezes to launch in February 2021.

The Penn \& Slavery Project app is cross platform, published for iOS and Android and developed in Unity. Dream Syndicate built the AR experiences on the foundation of ARKit (iOS) and ARCore (Android). The app utilizes world-space AR tracking, known as SLAM (Simultaneous Localization and Mapping), to detect the users' environment and place the AR experiences within their surroundings, either on-campus or remotely. The AR experiences are a combination of interactive 3D elements, video, and audio.

As Penn doctoral student Gladney explained, the point of the tour is to interrupt a user's experience of Penn's campus by making the university's history of complicity in slavery immediate and visible. Although immersive technology often provides users with a way to escape from the material constraints of their environments, Moody noted that this AR app is designed to prevent escape from uncomfortable historical facts. Project manager Taylor and former postdoctoral fellow Alexis Neumann defined the project's goals as making this history accessible to a larger audience, particularly to the surrounding Black community that has so often been harmed by the university's presence in West Philadelphia.

\section{Project Review}

\section{Elizabeth Losh}

The reckoning in higher education about its undeniable links to slavery, segregation, and ideologies of white supremacy predates many current digital humanities initiatives that attempt to document these ties. For example, Universities Studying Slavery. now 
reports over eighty affiliated institutions, including several from outside of the United States. Many of these participants have developed robust digital humanities projects that showcase archival records, oral histories, archeological artifacts, materials from community events, and other evidence of what Jody Allen, of the College of William \& Mary's The Lemon Project, has called the "journey of reconciliation" that every campus must eventually take.

In this context, the Penn \& Slavery Project is a notable addition to this growing corpus of anti-racist digital humanities work. It describes itself as a student-centered undertaking. According to the website, Penn \& Slavery was founded by students in 2017 and appears to have been run by them consistently since then. As such, it aims to focus on consciousness raising and the material and social conditions of the local environment. Although the project is currently directed by noted historian Kathleen Brown, undergraduate research often takes center stage. There are a few typographical errors that detract from the site's polish. Nonetheless, the voices of the undergraduates contribute a lot to its ethos as an active site of collaboration.

The site design features somber black-and-white aesthetics. The Omeka content management system serves as the main back-end technology for content management, and the site points to a GitHub site with access to code for the theme, which was developed by University of Pennsylvania librarians. Penn \& Slavery also has an augmented reality (AR) mobile app for smartphones, created by students in its design school, which provides a campus tour of significant sites in its history connected to slavery and scientific racism. I found the app easy to use, even hundreds of miles away from the GPS coordinates for which it was designed. The AR assets in the virtual exhibits were also polished and visually compelling and used archival photography, computer-generated sculptural forms, and reenactments respectfully and appropriately. Because sound design is such an important component of AR work about space and place, this might be seen as an important area for future investment.

Like many such projects, the decision to focus on the enslaved or the enslavers does not have an obvious answer. Digital humanities projects obviously want to give voice to the voiceless who have been excluded from the project of constructing public memory. At the same time it is important to demand accountability from institutions for celebrating their enslavers in the past and revealing their culpability. One section of the site is devoted to the topic of "Slave Ownership." It catalogues how trustees and early faculty depended on the bondage of African Americans. It includes Benjamin Franklin in this register of shame. Although he condemned slavery near the very end 
of his life, he profited both as a slave owner and as an editor of the Pennsylvania Gazette. The site notes that he "benefited financially from the advertisements for runaway slave and slave auction advertisements paid for by slave owners and traders." Near the bottom of the navigation bar, there is a link to "Enslaved People." As is often the case, there are fewer records documenting their lives and experiences. In the case of Caesar, an enslaved man who worked for the college and was remembered primarily for ringing the class bell, the site's editors acknowledge that they know "very little" about him and even less about the approximately 1,400 enslaved people in the immediate area.

Of particular interest to those in the medical humanities is the "Medical School" section, which addresses scientific racism and the treatment of human remains. The section on "Finances" tells the story of university fundraising trips to Jamaica and South Carolina. More use of maps, network graphs, or information visualizations might have told these stories somewhat more effectively. In other words, listing participants may be less effective than linking them.

Nonetheless, Penn \& Slavery merits attention for its many contributions in providing evidence that could move the campus forward in renaming structures and programs, repatriating remains, locating descendants deserving of compensation (perhaps in the form of scholarships), and recovering the histories of those who suffered while the university harvested all the fruits of their labor. 